\title{
A POSITIVE APPORTIONMENT FRAMEWORK TOWARDS ENHANCING COOPERATION IN THE JORDAN RIVER BASIN
}

\author{
ROLA QUBA'A, MUTASEM EL-FADEL, IBRAHIM ALAMEDDINE \& MAJDI ABOU NAJM \\ Department of Civil and Environmental Engineering, Faculty of Engineering and Architecture, \\ American University of Beirut, Lebanon
}

\begin{abstract}
The Jordan River Basin (JRB) has presented for long a sensitive water management challenge due to its direct association with water scarcity and socio-political conflicts amongst its riparians. This study emphasizes the limitations of existing bilateral agreements with respect to water allocation and argues for the potential of using renewable energy to catalyse a more lasting agreement within the basin based on mutual interest and benefit sharing beyond the river with third party involvement under the context of a "Positive Apportionment Framework". A SWOT analysis for the framework indicated that while there are incentives for all riparians and for third parties to collaborate towards attractive benefits, there are equally challenging weaknesses and threats. In an effort to rank the relative importance of these factors, the analytic hierarchy process (AHP) was applied. Responses from experts indicated that the highest influencing factors were the external threats stemming from regional politics and existing instability. These were followed by the weakness of the framework's ability to operate under existing economic disparities, regulatory and institutional discrepancies among riparian states, as well as deep-rooted socio-political conflicts between riparians. Still, highly influencing strengths and opportunities exist to build upon, such as the need to enhance water supply under an integrated water resources management and the potential for the framework to balance the bargaining power between riparians.
\end{abstract}

Keywords: transboundary water management, benefit-sharing, Jordan River Basin.

\section{INTRODUCTION}

Transboundary or shared water resources have invariably been prone to water conflicts because water is a vital resource basic to human survival and development. The complexity of managing rivers arises from disagreements over water allocation, riparians' contribution to water flows, historic uses, and future demands associated with social, ecological, and economic needs of each riparian [1]. While transboundary river basins have often been implied as sources of conflict [2]-[8], emphasizing the potential for cooperation through the co-management and co-development of such basins have been evolving especially with the increase in global water demand [4], [16]. Still, achieving improved transboundary water management (TWM) is intricate and varies from basin to basin [12].

The general framework for TWM revolves around several pillars entrenched in a vision for cooperation, river basin organizations and action programs, information sharing, third party support, and stakeholders' involvement. In this context, a vision of cooperation and ownership is a significant aspect towards achieving TWM. Further steps are imperative to ensure the availability of incentive benefits for all parties to induce the cooperation over transboundary waters [17]. Such benefits are usually planned using a benefit-sharing mechanism which may be defined as the cooperation of riparians towards achieving equitable utilization and sharing of benefits (and costs) resulting from water resources management and use [18], [19]. This approach aims to widen the basket of benefits and achieve a positive-sum outcome or a win-win framework through which all parties recognize cooperation to be more advantageous than non-cooperation. 
The approach becomes more significant when TWM is politicized in which case, pointing out economic incentives may generate the political will for cooperation and for overcoming difficulties in water negotiations due to power asymmetry between riparians [17], [20]. Further disparities, such as technical capacity or economic development, among riparians can be balanced through the involvement of third parties who can also play an active role in mediating negotiations and providing strong leadership to reach consensus and successful cooperation over water sharing [21], [22]. Past experience with benefit sharing defines four types of the latter: (i) benefits to the river, (ii) benefits from the river, (iii) the reduction in costs because of the river, and (iv) benefits beyond the river that extend regional cooperation beyond the boundaries of water allocation to other sectors of mutual interest [12], [19], [21], [26]. Three of the four categories focus on economic benefits, which can be generated from potential trade and exchange between the water and energy sectors as well as between water and food products (i.e. virtual water). Naturally, there are factors that support (such as fairness and concrete benefits) and others that hinder (such as scarcity of water and strength of the dominating riparian) the success of benefit sharing agreements. Empirical evidence shows that successful benefit sharing can take place with many well-documented examples such as the Lesotho Highlands Water Project, the Senegal River, the Scheldt and the Meuse River Basins, the Lancang-Mekong River Basin, and the Agreement in the Syr Darya basin/Aral Sea in Central Asia [19], [20], [22], [24].

In the Middle East, water conflicts between riparians has the potential to intensify due to water scarcity and increasing pressures associated with population growth, socio-economic development, and political instability. The Jordan River Basin (JRB) is a case in point with its water threatened by overexploitation and pollution from industrial, agricultural, municipal, and other anthropogenic sources [27]. Its riparians can no longer satisfy their needs from common resources without adversely affecting the water quantity and quality available to others, and without threatening the integrity of the basin's ecosystem. While water allocation plans were historically proposed and bilateral agreements exist among some riparians, the JRB conflict is not anticipated to be resolved in the absence of a multilateral agreement over the sharing of its waters. The potential for cooperation is hindered by historical political conflicts as well as recent on-going hostilities in the region. Conventional approaches relying on international water law for referring to sustainable water allocation schemes have proven their futility particularly in arid basins plagued with water scarcity, which is the case of the JRB. Hence, a clear win-win framework with attractive incentives is more likely to bring the riparians to a common ground. Hence, in this study, a benefit-sharing mechanism with energy as the catalyst is argued to develop a positive apportionment (win-win) planning and management framework for the JRB and encourage riparians to enter into negotiations over water allocation despite the persistence of challenges related to land tenure, security and sovereignty amongst other issues. Factors influencing the success of such a framework were examined using an AHP (Analytical Hierarchy Process) - SWOT (Strengths, Weaknesses, Opportunities, and Threats) analysis.

\section{THE POSITIVE APPORTIONMENT FRAMEWORK}

\subsection{A benefit-sharing based framework}

This study argues for a new cooperation framework, which will be referred to as the "Positive Apportionment Framework", and develops it with attractive incentives to bring riparians to a common ground and create the vision of cooperation. The proposed framework revolves 
around three main pillars: (1) a positive-sum arrangement in the water reallocation scheme [28]; (2) economic incentives to increase the chance of cooperation of riparians especially those having to replace current water use; and (3) benefits to third parties who may sponsor the projects/programs under this cooperation. Such elements will create the benefits to be able to achieve the vision of cooperation and penetrate into the cycle of transboundary water management.

A positive-sum arrangement entails water reallocation based on replacement, whereby the party that would "give up" water from the JRB is compensated with water quantities from alternative source(s) [28]. Such a plan naturally requires securing additional sources or developing "new water" mainly through seawater desalination. The Red Sea-Dead Sea Conveyance project is promising in this regards and can enhance the cooperation between Jordan, Israel, and the PA through the construction of a 180km conveyor within the Jordanian territory to transport seawater from the Gulf of Aqaba on the Red Sea to the southern end of the Dead Sea area for desalination thus taking advantage of the 400 meter elevation difference between the Red Sea and Dead Sea to generate the power that operates the desalination plant and at the same time help raise and stabilize the level of the Dead Sea. The project is expected to add $850 \mathrm{MCM}$ of new water to the basin [29]. However, securing "new water" may not be an adequate strategy for cooperation in the case of the JRB, given that Israel, which uses the largest share of the JRB water, has already developed several desalination plants to secure "new water". As such, additional economic incentives emerge as vital elements towards attracting riparians into cooperation, especially Israel. Those economic incentives could be attained through the proposed development of a regional solar energy grid [30]. Such a grid allows for efficient energy use, lower electricity cost, and additional energy supply that can be transmitted through existing interconnections proposed between the electrical grids of Egypt, Iraq, Jordan, Lebanon, Libya, Palestine, Syria, and Turkey [31]. Several other larger plans have been contemplated to interconnect power grids throughout the Middle East, North Africa, and Europe [31], [32]. Under such a framework, Israel can benefit from connecting to these energy grids in return for cooperating in the JRB water reallocation schemes. These benefits can also be in the form of providing Israel with inexpensive energy to run its desalination program since energy is known to account for $55 \%$ of a desalination plant's operation and maintenance costs [33]. Providing Israel with low cost renewable energy to feed its coastal desalination program may act as an attractive economic incentive. Similarly, renewable energy is critical for Jordan that is embarking on the development of the Jordan Red Sea Project to desalinate the Red Sea water and eventually pump it to Amman. Pumping the water to Amman is energy intensive due to elevation difference between the desalination location along the Dead Sea shore at around 400 meters below sea level to Amman City at an altitude starting from 700 meters above sea level.

The technical feasibility of renewable energy-based a framework is high given that: (1) the Gulf Cooperation Council and North African states already possess interconnected grids able to support systematic intra-regional electricity trade with Europe, (2) North Africa is already part of a grid that is connected to Europe, and (3) the vision for developing interconnected electric power transmission grids among Mediterranean countries is taking shape (i.e. the Mediterranean Ring project and the Desertec Industrial Initiative). Yet for the plan to succeed, a political clout formed from international players remains critical. Europe's desire to increase its reliance on renewable energy sources may encourage its commitment to provide financial subsidies towards the creation of such a framework and hence may be considered as a potential stakeholder [19]. In this context, the GCC and the European Union, being the main energy supply and demand centers respectively, can constitute a third party 
with inherent interest in achieving political stability and security (Fig. 1) needed to safeguard energy routes passing through the JRB.

Other parties may include the United Nations (UN) organizations and international banks such as the World Bank, as well as other regional players including the US, Russia, and Iran.

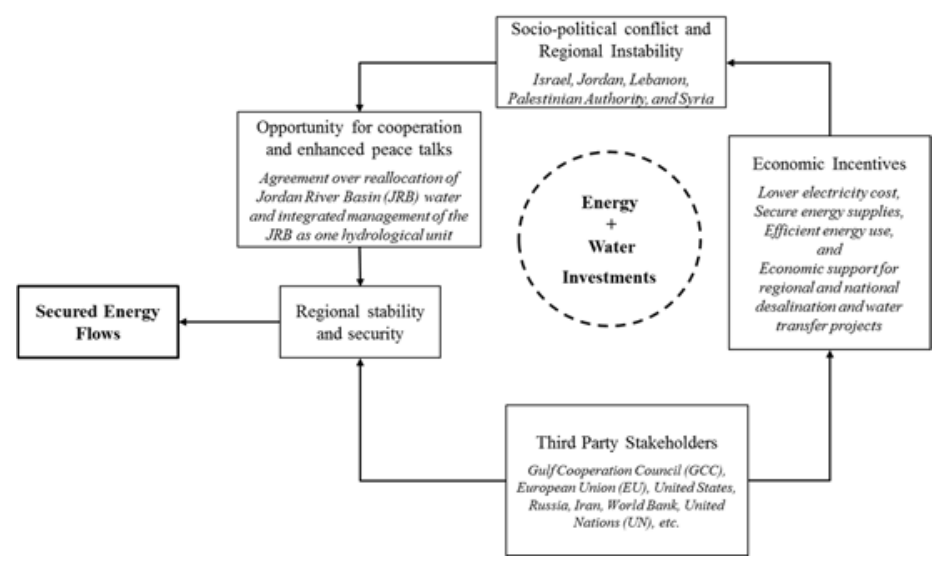

Figure 1: Positive apportionment framework towards constructive engagement.

Table 1: SWOT analysis for the positive apportionment framework.

\begin{tabular}{|c|c|}
\hline $\begin{array}{l}\text { Strengths } \\
\text { What are the internal factors that give the } \\
\text { framework advantage over other options? }\end{array}$ & $\begin{array}{l}\text { Weaknesses } \\
\text { What are the internal factors impeding the } \\
\text { development of the proposed framework? }\end{array}$ \\
\hline $\begin{array}{l}\text { - S1: Benefit sharing among riparians and third } \\
\text { parties through investment in solar energy. } \\
\text { - S2: Equal bargaining power amongst riparians by } \\
\text { linking cooperation over water and energy. } \\
\text { - S3: Third party support may facilitate mediation } \\
\text { of political discords. } \\
\text { - S4: Existing trend of third parties seeking to } \\
\text { develop investments in solar energy. } \\
\text { - S5: Enhancing IWRM and facing environmental } \\
\text { challenges (i.e. water quality and Dead Sea } \\
\text { declining level). }\end{array}$ & $\begin{array}{l}\text { - W1: Power asymmetry, economic disparity, } \\
\text { regulatory and institutional discrepancies } \\
\text { among riparians coupled with deep-rooted } \\
\text { socio-political conflicts. } \\
\text { - W2: Riparians refusal to negotiate over the } \\
\text { reallocation of the JRB water resources. } \\
\text { - W3: Unilateral approaches in water resources } \\
\text { management. } \\
\text { - W4: Bilateral agreements jeopardizing a multi- } \\
\text { lateral approach. } \\
\text { - W5: Regional security jeopardizing third party's } \\
\text { willingness to investment. }\end{array}$ \\
\hline $\begin{array}{c}\text { Opportunities } \\
\text { What are the external factors that could be taken } \\
\text { advantage of to support the framework? }\end{array}$ & $\begin{array}{c}\text { Threats } \\
\text { What are the external factors that represent } \\
\text { potential constraints to the framework? }\end{array}$ \\
\hline $\begin{array}{l}\text { - O1: Riparians seeking to enhance water supply. } \\
\text { - O2: Safe and sustainable renewable energy for } \\
\text { riparians and third parties to meet growing } \\
\text { energy demands. } \\
\text { - O3: Relying on solar energy instead of } \\
\text { controversial development of nuclear energy. } \\
\text { - O4: Reduction in Europe's carbon emissions. } \\
\text { - O5: Increased investment in solar energy towards } \\
\text { more affordable technology. }\end{array}$ & $\begin{array}{l}\text { - T1: Low efficiency of solar technology and } \\
\text { storage challenges. } \\
\text { - T2: Relatively high cost of solar technology } \\
\text { compared to conventional oil and gas energy. } \\
\text { - T3: Natural gas recently discovered by some } \\
\text { riparian may weaken interest in cooperation. } \\
\text { - T4: Political unrest threatening the integration of } \\
\text { regional grids within safe corridors. } \\
\text { - T5: Threat that political decisions might not } \\
\text { support adoption of the Positive } \\
\text { Apportionment Framework due to potential } \\
\text { vagueness of political rational. }\end{array}$ \\
\hline
\end{tabular}




\subsection{SWOT analysis}

An analytical-based SWOT (Strengths, Weaknesses, Opportunities, Threats) analysis was conducted to shed light on internal and external factors affecting the proposed Positive Apportionment Framework by identifying and examining factors potentially influencing the SWOT elements (Table 1).

The SWOT analysis (Table 3) showed that the framework's major strength relates to having a basket of economic benefits generated by linking cooperation over water allocation with cooperation over regional renewable energy grids to pass through the JRB riparian countries (S1). Such benefit-based arrangements have shown resilience to political changes as in the case of the Lesotho Highlands Water Project on the Senqu River through which South Africa purchased water rights from Lesotho and the latter used the payments towards developing the project [35]. The economic benefits to be generated can enhance the bargaining power of the weaker riparians and assist in managing the existing political discord (S2). In addition, the involvement of third parties with a vested interest in the generated benefits may reduce the existing Arab-Israeli political tension that is affecting the JRB (S3 and S4). Finally, a multi-lateral agreement involving JRB riparians could present a greater opportunity of facilitating integrated water resources management (IWRM) for the basin and consequently provides a prospect for addressing major challenges within the JRB, including the deteriorating water quality, the declining Dead Sea level, and the lack of agreement over management of its shared water resources (S5).

On the other hand, weaknesses that may act against the success of the framework and hinder the willingness to cooperate include the economic disparity among riparians, where Israel is considered to have established the strongest economy in the region while other riparians are still struggling in building their economies especially within the JRB areas. Similar developmental differences are encountered at the regulatory and institutional structures that are integral to the development of a regional renewable solar energy grid (W1). Developmental imbalances among riparian countries are further complicated by the ArabIsraeli deep-rooted socio-political conflict. To date, Syria and Lebanon were not able to negotiate with Israel (W2) and the riparians are proceeding unilaterally with addressing their water concerns with Israel investing in a local desalination program along its coastal areas and Jordan working towards the Jordan Red Sea Project (W3). Furthermore, existing bilateral agreements (Jordan-Syria, Israel-Jordan, and Israel-PA) might weaken the resolve of riparians especially in the lower JRB to enter into a new comprehensive multi-lateral agreement (W4). Last, but not least, third party support, a cornerstone in the framework structure, is tied to willingness to invest in shared renewable energy projects (W5). In the event that third parties do not perceive significant economic return on investment, they will inevitably not provide the requested support.

Still, a variety of external factors are available to influence the framework's success including the fact that all riparians are seeking to enhance their water supply resources (O1) and that third parties, especially Europe, are seeking alternative sources to meet their growing energy demand with emphasis on renewable sources as a safe and sustainable clean energy that is gaining ground in Europe $(\mathrm{O} 2)$. Moreover, the possibility to invest in renewables can concurrently assist Europe in achieving its target emissions reductions from energy systems (O4). Moreover, solar energy is growing into a reliable source with a continuous decline in cost due to developments in its underlying technology (O5). This is noted from countries reported targets to increase the share of renewable sources (solar and wind) in their final energy consumption where Israel plans to reach $13 \%$ by 2025 , Jordan $11 \%$ by 2025 , Lebanon $12 \%$ by 2020 , and the PA $25 \%$ by 2020 [36]. 
The threats of external risks are mostly at the technical and political levels. Technically, developments in renewable energy to date do not allow the complete substitution of conventional energy sources because the efficiency of solar technology in generating electricity is still relatively low (reportedly at $\sim 22 \%$ for solar panels) with limitations on storage capacity and the need to have in other emergency fuel-based generators in case of shortfall in output (T1). Moreover, renewable energy prices (solar and wind) are considered to be higher than the conventional oil and gas energy (T2). Still, reports from year 2016 indicate that renewable energy prices are now almost the same as that of fuel and would continue to decline with technological advancements. Gas energy in particular remains a strong competitor in the energy market with the Levant riparians along the eastern Mediterranean region (Israel, Lebanon, and Syria) recently exploring natural gas potentials, which might weaken their interest in cooperation (T3). The other source of concern is the fact that the integration within a renewable solar energy grid requires peace and safe corridors of passage. The persistence of current political unrest in the region in general and in Syria / Iraq in particular, can sabotage regional electricity grids and related infrastructure investments posing an eminent risk (T4). Besides, the political situation in the region at present is considered to be chaotic with a threat of irrational political decisions (T5).

\subsection{AHP-SWOT analysis}

A main limitation of SWOT is that the importance of each factor cannot be quantified to determine which factor has the greatest influence on the framework [37]. To overcome this limitation, the Analytical Hierarchy Process (AHP), which is a Multi-criteria Decision Analysis (MCDA) method, was applied to evaluate and prioritize the SWOT factors [37]-[39]. The AHP was used because of its simplicity and ability to make qualitative attributes commensurable for prioritising or for relative importance ranking by transforming the subjective judgments into objective evaluation [39]-[41]. The AHP presents also the ability to calculate a consistency index to check on the reliability of the results [38].

Accordingly, a rating system (Table 2) was adopted based on Saaty's [42] rating that uses a scale from 1 to 9 with their reciprocals (i.e., 1/2, 1/3, 1/4, 1/5, 1/6, 1/7, 1/8, and 1/9). However, a pilot testing of the full-scale pair-wise comparison proved to be too tedious for respondents and a simpler scale allowed for a smoother pair-wise comparison using the terms of "equally", "slightly less/more", or "strongly less/more". These terms corresponded to 1, $1 / 3,3,1 / 7$, and 7 on Saaty's scale and were adopted for the comparison with the scales referring to terms "more/less" (scale 5) and "absolutely more/less" (scale 9) dropped along with the intermediary terms represented by scales 2, 4, 6 and 8 .

Around 42 experts in related fields were contacted to carry the pair-wise comparison to the SWOT groups and the factors within each group. 27 responded and the consistency of their comparisons was checked by calculating the random consistency index (CI) and the consistency ratio (CR) as expressed in eqns (1) and (2).

Table 2: Rating system for pairwise comparison of the SWOT factors and groups.

\begin{tabular}{cl}
\hline Importance & Linguistic of the Scale \\
\hline $1 / 7$ & $i$ is strongly less important than $j$ \\
$1 / 3$ & $i$ is less important than $j$ \\
1 & $i$ is equally important as $j$ \\
3 & $i$ is more important than $j$ \\
7 & $i$ is strongly more important than $j$ \\
\hline
\end{tabular}




$$
\begin{gathered}
C I=\frac{\lambda_{\max }-n}{n-1}, \\
C R=\frac{C I}{R I},
\end{gathered}
$$

where $\mathrm{CI}=$ Consistency Index; $\mathrm{n}=$ Size of the square matrix (i.e. number of SWOT factors/groups); $\lambda_{\max }=$ Largest eigenvector of the matrix; $\mathrm{CR}=$ Consistency Ratio. $\mathrm{CR} \leq 9 \%$ for $n=4$ and $\leq 10 \%$ for $n=5$ [42]; RI $=$ Random Index. $R I=0.90$ for $n=4$; and RI $=1.12$ for $\mathrm{n}=5[42]$.

The responses exceeding specified limits of the CR were excluded. For the consistent responses, the geometric averages of the weights derived for the SWOT groups and factors from each respondent were calculated. Then, the ranking of the SWOT factors for relative importance was carried by multiplying the factor's local weight (i.e. its relative importance within its group) by the specific group weight to yield an overall weight representing the factor's overall rank among SWOT factors [37], [39]. Of the 27 responses, 22 had a valid SWOT groups comparison (i.e. CI $<9 \%$ ), 19 respondents had a valid comparison of the weaknesses factors (i.e. CI $<10 \%$ ), and 22 respondents had valid comparison of factors within the strengths, opportunities and threats groups (i.e. $\mathrm{CI}<10 \%$ ).

\begin{tabular}{|c|c|c|c|c|c|c|c|}
\hline $\begin{array}{l}\text { SWOT } \\
\text { Group }\end{array}$ & $\begin{array}{l}\text { Group } \\
\text { Weight }\end{array}$ & Priority & & Factors & $\begin{array}{c}\text { Local } \\
\text { Weight }\end{array}$ & $\begin{array}{l}\text { Overall } \\
\text { Weight }\end{array}$ & Ranking \\
\hline \multirow{5}{*}{$\begin{array}{l}\text { Strengths } \\
\text { (S) }\end{array}$} & \multirow{5}{*}{0.211} & \multirow{5}{*}{2} & S1: & Benefit sharing & 0.1236 & 0.0260 & 12 \\
\hline & & & S2: & Equal bargaining power & 0.1950 & 0.0411 & 5 \\
\hline & & & S3: & Third party support & 0.1408 & 0.0297 & 11 \\
\hline & & & S4: & Investments in solar energy & 0.1085 & 0.0229 & 18 \\
\hline & & & S5: & $\begin{array}{l}\text { Enhancing integrated water } \\
\text { resources management }\end{array}$ & 0.2208 & 0.0465 & 4 \\
\hline \multirow{5}{*}{$\begin{array}{l}\text { Weaknesses } \\
\text { (W) }\end{array}$} & \multirow{5}{*}{0.188} & \multirow{5}{*}{3} & W1: & $\begin{array}{l}\text { Power and developmental } \\
\text { asymmetries }\end{array}$ & 0.1992 & 0.0374 & 6 \\
\hline & & & W2: & Riparians refusal to negotiate & 0.1827 & 0.0343 & 7 \\
\hline & & & W3: & Unilateral approaches & 0.1319 & 0.0248 & 15 \\
\hline & & & W4: & Bilateral agreements & 0.1137 & 0.0213 & 19 \\
\hline & & & W5: & Regional security & 0.1580 & 0.0297 & 10 \\
\hline \multirow{5}{*}{$\begin{array}{l}\text { Opportunities } \\
\text { (O) }\end{array}$} & \multirow{5}{*}{0.176} & \multirow{5}{*}{4} & O1: & Need to enhance water supply & 0.2919 & 0.0513 & 3 \\
\hline & & & $\mathrm{O} 2:$ & $\begin{array}{l}\text { Safe and sustainable renewable } \\
\text { energy }\end{array}$ & 0.1786 & 0.0314 & 8 \\
\hline & & & O3: & Relying on solar energy & 0.1311 & 0.0230 & 17 \\
\hline & & & O4: & $\begin{array}{l}\text { Reduction in Europe's carbon } \\
\text { emissions }\end{array}$ & 0.0985 & 0.0173 & 20 \\
\hline & & & O5: & $\begin{array}{l}\text { Increased investment in solar } \\
\text { energy }\end{array}$ & 0.1432 & 0.0252 & 14 \\
\hline \multirow{5}{*}{$\begin{array}{l}\text { Threats } \\
\text { (T) }\end{array}$} & \multirow{5}{*}{0.250} & \multirow{5}{*}{1} & T1: & $\begin{array}{l}\text { Low efficiency of solar } \\
\text { technology and storage } \\
\text { challenges }\end{array}$ & 0.0982 & 0.0246 & 16 \\
\hline & & & & $\begin{array}{l}\text { Relatively high cost of solar } \\
\text { technology }\end{array}$ & 0.1214 & 0.0304 & 9 \\
\hline & & & & $\begin{array}{l}\text { Natural gas recently discovered } \\
\text { by some riparians }\end{array}$ & 0.1019 & 0.0255 & 13 \\
\hline & & & T4: & Political unrest & 0.2463 & 0.0617 & 1 \\
\hline & & & T5: & Threat of political decisions & 0.2367 & 0.0593 & 2 \\
\hline
\end{tabular}

Table 3: The framework's prioritized SWOT groups and factors based on AHP results. 
Table 3 presents the results of the weights obtained for each SWOT group, the local weight for each factor within its group, the overall weight that each factor got by multiplying the factor local weight with its corresponding group weight, and the ranking for each factor. The group weights revealed that external threats and internal strengths are perceived as the most influential SWOT elements. Based on the AHP ranking results, the most critical factors threatening the failure of the framework are the current political unrest in the region (T4) followed by whether or not political decisions would support adoption of the framework (T5). Though the two highest ranking factors were threats, they were followed by opportunities and strengths that tend to enhance the success of the framework. The third influencing factor was that riparians are seeking to enhance their water supply (O1). According to the AHP (Table 3), this is one of the strongest advantages of the framework that could be argued to enhance its success. Other advantages ranking as $4^{\text {th }}$ and $5^{\text {th }}$ include the framework's ability to achieve IWRM within the JRB (S5) and the equal bargaining power it can create among the basin's riparians (S2). The most significant weaknesses affecting the framework ranked $6^{\text {th }}$ and $7^{\text {th }}$ and were the fact that the countries have varying degrees of development even in terms of regulatory and institutional structures (W1) and that the riparians refuse to negotiate (W2), respectively.

Overall, the AHP-SWOT results reflect the significance of political influence over such a framework. This implies that third parties, especially Europe whose main interest stems from its need to diversify sources of energy, need to take an active role in overcoming those threats. Assuming the threat of political will and the power imbalances are overcome, the success of the framework still requires addressing the regulatory and institutional capacity differences among riparians and guaranteeing the effectiveness of regulatory systems.

\section{CONCLUSION}

In closure, a solution to the challenges of water scarcity in the JRB is argued to be achieved independently of the wider problem of regional peace over the land. Such a solution has been proposed under a benefit-sharing framework that links cooperation over water with cooperation initiatives over renewable solar energy. While creating such a water-energy nexus provides incentives for all riparians and for third parties to collaborate towards attractive benefits, the AHP-SWOT analysis shows that there are challenging weaknesses and threats to consider including the power asymmetry and difference in economic development of riparian countries as well as the political unrest witnessed throughout the region coupled with threat of lack of political support. Still, there are strengths and opportunities to build upon, especially if third party support succeeded in smoothing out the major challenges. The factors supporting the framework's success related to the riparians need to enhance their water supplies and the opportunity for equalizing the bargaining power for all riparians to facilitate reaching an integrated transboundary river basin management plan for the JRB.

\section{ACKNOWLEDGEMENT}

Special thanks are extended to Dar Al-Handasah (Shair \& Partners) for its support to the graduate programs at the American University of Beirut.

\section{REFERENCES}

[1] Atalan, N., Transboundary Rivers. Encyclopedia of Environment and Society, ed. P. Robbins, SAGE Publications, pp. 1765-1767, 2007.

[2] Butts, K., The strategic importance of water. Parameters, pp. 65-83, 1997. 
[3] Homer-Dixon, T.F., Environmental scarcities and violent conflict: Evidence from cases. International Security, 19, pp. 5-40, 1994.

[4] Gleick, P., Water and conflict: Fresh water resources and international security. International Security, 1(1), pp. 79-112, 1993.

[5] Homer-Dixon, T.F., On the threshold: Environmental changes as causes of acute conflict. International Security, 16(2), pp. 76-116, 1991

[6] Lipschutz, R.D., When Nations Clash: Raw Materials, Ideology and Foreign Policy, Cambridge, MA, Ballinger, 1989.

[7] Westing, A., Global Resources and International Conflict: Environmental Factors in Strategic Policy and Action, Oxford University Press: New York, 1986.

[8] Gurr, T.R., On the political consequences of scarcity and economic decline. International Studies Quarterly, 29, pp. 51-75, 1985.

[9] Bhagabati, S. et al., A cooperative game analysis of transboundary hydropower development in the Lower Mekong: Case of the $3 \mathrm{~S}$ sub-basins. Water Resources Management, 28, pp. 3417-3437, 2014.

[10] Bhaduri, A. \& Liebe, J., Cooperation in transboundary water sharing with issue linkage: Game-theoretical case study in the Volta Basin. Journal of Water Resources Planning and Management, 139, pp. 235-245, 2013.

[11] MacQuarrie, P.R. et al., Promoting cooperation in the Mekong region through water conflict management, regional collaboration, and capacity building - GMSARN (Great Mekong Subregion Academic and Research Network). International Journal, 2, pp. 175-184, 2008.

[12] UN Water (United Nations Task Force on Transboundary Waters). Transboundary Waters: Sharing Benefits, Sharing Responsibilities, United Nations Office to Support the International Decade for Action 'Water for Life' 2005-2015 (UN-IDfA), Zaragoza, Spain, 2008.

[13] Dinar, S., International Water Treaties: Negotiation and Cooperation Along Transboundary Rivers, Routledge: London, 2008.

[14] Uitto, J.I. \& Duda, A., Management of transboundary water resources: Lessons from international cooperation for conflict prevention. The Geographical Journal, 168(4), pp. 365-378, 2002.

[15] Wolf, A., Conflict and cooperation along international waterways. Water Policy, 1(2), pp. 251-265, 1998.

[16] Rogers, P., The value of cooperation in resolving international river basin disputes. Natural Resources Forum, 17(2), pp. 117-131, 1993.

[17] Jägerskog, A. \& Zeitoun, M., Getting transboundary water right: Theory and practice for effective cooperation. Report Nr. 25. SIWI (Stockholm International Water Institute), Stockholm, 2009.

[18] Hensengerth, O. et al., Benefit-sharing in dam projects on shared rivers. Discussion Paper 6/2012, German Development Institute, Bonn, 2012.

[19] MRC (Mekong River Commission), Knowledge base on benefit sharing, volume 1 of 5, summary and guide to the knowledge base compendium. MRC Initiative on Sustainable Hydropower, 2011.

[20] Earle, A. et al., Transboundary Water Management: Principles and Oractice. Earthscan: London.

[21] Mostert, E., How can international donors promote transboundary water management? Discussion Paper 8/2005, German Development Institute, Bonn, 2005.

[22] Qaddumi, H., Practical approaches to transboundary water benefit sharing. Working Paper 292, Overseas Development Institute, London, 2008. 
[23] Dombrowsky, I., Revisiting the potential for benefit sharing in the management of trans-boundary rivers. Water Policy, 11, pp. 125-140, 2009.

[24] Van der Zaag, P., Asymmetry and equity in water resources management; Critical institutional issues for Southern Africa. Water Resources Management, 21, pp. 1993-2004, 2007.

[25] Sadoff, C. \& Grey, D., Cooperation on international rivers: A continuum for securing and sharing benefits. Water International, 30(4), pp. 420-427, 2005.

[26] Sadoff, C. \& Grey, D., Beyond the river: The benefits of cooperation on international rivers. Water Policy, 4(5), pp. 389-403, 2002.

[27] Becker, N. et al., Desalinate or divert? Coastal non-market values as a decision tool for an integrated water management policy: The case of the Jordan River basin. Ocean and Coastal Management, 64, pp. 27-36, 2012.

[28] Phillips, D.J.H. et al., The Jordan River Basin: 2. Potential future allocations to the co-riparians. Water International, 32(1), pp. 39-62, 2007.

[29] World Bank, Red Sea-Dead Sea Water Conveyance Study Environmental and Social Assessment: Preliminary draft environmental and social assessment (ESA) - Executive Summary. Prepared by Environmental Resources Management (ERM) Limited, BRL Ingenierie, and EcoConsult, 2012.

[30] Siteresources.worldbank.org/INTREDSEADEADSEA/Resources/Environmental_ and_Social_Assessment_Summary_EN.pdf Accessed on: 10 May 2017.

[31] Desertec, The Desertec Concept. http://www.desertec.org/the-concept Accessed on: 3 May 2017.

[32] Meisen, P. \& Tatum, J., The Water-Energy Nexus in the Jordan River Basin: The potential for building peace through sustainability. Global Energy Network Institute (GENI), 2011.

[33] MED-EMP (Support for the Enhanced Integration and the Improved Security of the Euro-Mediterranean Energy Market), Regional Cooperation Brochure 2010. Online. https://ec.europa.eu/europeaid/sites/devco/files/publication-regional-cooperationmediterranean-partnership-2010_en.pdf. Accessed on: 3 May 2017.

[34] WATEREUSE ASSOCIATION. Seawater Desalination Costs White Paper, 2012. watereuse.org/wp-content/uploads/2015/10/WateReuse_Desal_Cost_White_Paper. pdf. Accessed on 11 May 2017.

[35] Tenne, A. Sea Water Desalination in Israel: Planning, coping with difficulties, and economic aspects of long-term risks, State of Israel, Water authority, Desalination Division, 2010.

[36] www.water.gov.il/Hebrew/Planning-and-Development/Desalination/Documents/ Desalination-in-Israel.pdf. Accessed on: 13 Apr. 2017.

[37] Wolf, A.T. \& Newton, J.T., Case studies of transboundary dispute resolution appendix C, Managing and Transforming Water Conflicts, eds D.P. Jerry \& A.T. Wolf, Cambridge: Cambridge University Press, 2008. www.transboundarywaters.orst.edu/research/casestudies/. Accessed on: 10 May 2017.

[38] REN21 (Renewable Energy Policy Network for the $21^{\text {st }}$ Century), Renewables 2016 Global Status Report, 2016. Online. http://www.ren21.net/wpcontent/uploads/2016/06/GSR_2016_Full_Report.pdf Accessed on: 18 May 2017.

[39] Gorener, A. et al., Application of combined SWOT and AHP: A Case study for a manufacturing firm. Procedia - Social and Behavioral Sciences, 58, pp. 1525-1534, 2012. 
[40] Banihabib, M.E. et al., A new framework for strategic planning to stabilize a shrinking lake. Lake and Reservoir Management, 31(1), pp. 31-43, 2015.

[41] Kurttila, M. et al., Utilizing the analytic hierarchy process (AHP) in SWOT analysis A hybrid method and its application to a forest-certification case. Forest Policy and Economics, 1, pp. 41-52, 2000.

[42] Kajanus, M. et al., Making use of MCDS methods in SWOT Analysis-Lessons learnt in strategic natural resources management. Forest Policy and Economics, 20, pp. 1-9, 2012.

[43] Sipahi, S. \& Timor, M., The analytic hierarchy process and analytic network process: An overview of applications. Management Decision, 48(5), pp. 775-808, 2010.

[44] Saaty, T.L., The Analytic Hierarchy Process, McGraw-Hill Inc.: New York, 1980. 